NBER WORKING PAPER SERIES

\title{
CHINA'S INVESTMENT IN HUMAN CAPITAL
}

\author{
James J. Heckman
}

Working Paper 9296

http://www.nber.org/papers/w9296

\author{
NATIONAL BUREAU OF ECONOMIC RESEARCH \\ 1050 Massachusetts Avenue \\ Cambridge, MA 02138 \\ October 2002
}

Heckman is Henry Schultz Distinguished Service Professor at the University of Chicago and a Senior Fellow of the American Bar Foundation. This work was supported by the American Bar Foundation. He received the Nobel Prize in Economics in 2000. He thanks D. Gale Johnson and two anonymous referees for their comments. The views expressed herein are those of the authors and not necessarily those of the National Bureau of Economic Research.

(C) 2002 by James J. Heckman. All rights reserved. Short sections of text, not to exceed two paragraphs, may be quoted without explicit permission provided that full credit, including (C) notice, is given to the source. 
China's Investment in Human Capital

James J. Heckman

NBER Working Paper No. 9296

October 2002

JEL No. O15

\title{
ABSTRACT
}

This paper discusses evidence on human capital investment in China. Policies through the mid 1990s favor physical investment over schooling.

\author{
James J. Heckman \\ Department of Economics \\ University of Chicago \\ 1126 E. 59th Street \\ Chicago, IL 60637 \\ and NBER \\ jjh@uchicago.edu
}


China, at all levels of government, currently spends about 2.5\% of its GDP on investment in schooling. ${ }^{1} \quad$ At the same time, roughly $30 \%$ of its GDP is devoted to physical investment. In the U.S., these figures are $5.4 \%$ and $17 \%$ respectively. In South Korea, they are $3.7 \%$ and $30 \%$. See Table 1 for a comparison of China with other countries in its expenditure of GDP on education. China is below average even among its peers in its expenditure on investment in people. Its ratio of annual investment in physical capital to human capital is much higher than that in most countries around the world.

Perhaps this imbalance is warranted. Perhaps the economic rate of return to physical capital is much greater than the economic rate of return to physical capital. Below, I summarize evidence that indicates that the true rate of return to education and skill formation is very high and that the imbalance revealed in Table 1 is symptomatic of a serious distortion in current policy that serves to retard economic development in China. A basic result of economics is that resources should flow to their most productive use. A policy that equalizes returns across all investment types increases economic growth. Current Chinese policy ignores this fundamental rule and thereby retards the economic growth of China.

In this paper, I first present the potential benefits that flow from investment in human capital. Then I discuss the empirical evidence on the rate of return to education in China. I next consider alternative policy reforms that would foster skill acquisition and enable China to harvest the benefits of investment in human capital.

\footnotetext{
${ }^{1}$ See UNESCO, 1999.
} 


\section{The Benefits of Human Capital Investment}

When economists began to measure the sources of economic growth, what previously had been considered an unexplained residual - an unexplained factor - became identified as human capital. From studies of the development of the American economy, and the sources of growth of many countries around the world, it has become evident that human capital-the skill of the population-plays a major role in the productivity of nations. (Schultz, 1981)

It is analytically useful to think of human capital as another, very valuable, kind of capital. The term "human capital" sometimes suggests a depersonalization of the individual and is associated in the popular mind with a dehumanizing society that equates men with machines. In fact, it is just the other way around. The human capital concept recognizes that human beings are as important, if not more important, than physical capital in creating wealth and generating a successful economy. It is an appropriate concept for a People's Republic. To understand how human capital affects the economy and why China should promote it, consider how human capital improves productivity.

First of all, human capital is productive because of its immediate effect on raising the skills of workers. So, for example, if you train an individual to be a better accountant, the accounting performance of that individual will rise. If you train a worker to fix an engine, the worker will be more productive in fixing engines. These are the obvious direct effects of making people more skilled.

But human capital also improves the adaptability and allocative efficiency of resources 
in society. It allows agents to allocate resources more effectively across tasks. It enhances the ability of agents to adapt to change and to respond to new opportunities. (Schultz, 1975)

China is changing. Its labor markets, and capital markets are changing. Indeed, the world economy is changing. An empirical regularity that has emerged in numerous empirical studies is that more educated people and better skilled people are better adapted to change. They are able to benefit from opportunities that become available and create new opportunities of their own. They enhance productivity in the workplace. Greater skill also facilitates worker mobility across occupations, industries and regions in response to new opportunities, and helps people reallocate resources, both human and physical, toward more productive opportunities, and even to realize that those opportunities exist. A more educated workforce is a more flexible workforce. More educated people are better able to absorb new ideas, adapt to foreign technologies, improve local technologies, and understand and apply knowledge from outside China to local situations.

As China enters world markets, it will have access to newer forms of technology and organizational arrangements. The need for a more skilled workforce will increase. The new technology being brought into China by its investment in physical capital requires more skilled workers to operate it. Capital and skill are complementary. Each factor raises the productivity of the other. An investment strategy that emphasizes physical capital to the exclusion of human capital fails to capture the benefits that can arise from a more balanced investment strategy. It takes skilled workers to make the most efficient use of modern technologies. 
Numerous studies of agriculture in China and around the world reveal that education promotes productivity on the farm, and also helps the agricultural sector to adapt to changing markets and technologies. More educated farmers are better able to exploit opportunities in technology and trade. The development process is characterized by emerging technologies, emerging options, and by improved choices. Better-educated people are better able to make good choices. (Yang, 2001)

Since so many studies from around the world demonstrate that education and skills are important determinants of economic growth, an important question for China and for many other countries, is whether or not there is adequate investment in human capital. Is there under-investment in education or over-investment in education, relative to other types of investment?

When we think about an appropriate investment strategy for China, and the development of its Western region, it is very important to understand that optimizing over the full portfolio of investments-both human and physical capital-promotes the highest rate of growth. If China over-invests in one type of capital or under-invests in another, opportunities for improvement in wealth are lost. By equalizing returns across assets and across markets in different regions of the country, greater national wealth will be produced.

So a major question for China's leadership is whether there is under-investment or over-investment in education in China. Should the Chinese investment portfolio be readjusted? 


\section{Under-Investment in Human Capital?}

There is a low level of public support for education in most regions of China. Since schooling is mostly funded at the local level, rich provinces produce more human capital per capita then do poor provinces. The place of a person's birth is one of the most important determinants of that person's skill level. Resource constraints affect access to schooling of individuals differently in different parts of China, especially in Western China. Access to education is not uniform across regions. This creates serious regional disparities and is a major source of inefficiency in current policy. (Li, undated)

A second reason to think that there might be under-investment in human capital is that there are benefits to education that are not directly captured by individuals. These externalities are likely to be quite large in China. For example, a better educated workforce produces new ideas and knowledge. Individuals may not capture all of the gains produced from their education, especially if the wages of the skilled are held down by policy, as they are in China. Collectively, educated workers produce great gain. So on the face of it, there is under-investment in human capital in China and in many other countries around the world.

What does the empirical evidence on the rate of return to education in the Chinese economy show? It is important to evaluate government activity on a quantitative basis, to screen the bad investments from the good ones, and to conduct policy on a factually informed basis. From cost-benefit analyses grounded in data, we can understand more clearly whether human capital projects or physical capital projects should be favored, and 
in what proportions. In making judgments by cost benefit criteria, society can use its resources most efficiently.

In the Chinese context, this is especially important, given that resources are scarce, and that the country as a whole is poor. So it is especially important to make wise investment decisions here.

If you look at the data on the rate of return to education in order to develop a factually informed policy, you come up with a big surprise. Estimating the rate of return to education in China in the way economists in Western economies ordinarily do, you will find that the rate of return to education in China in the early 1900 s is about $4 \%$. (Chow, 2001) This is a low rate of return. It is far below the rate of return to physical capital in industry that is estimated by some to be as high as $20 \%$. (Chow, 1993) More recent estimates suggest that this return is $7 \%$ in 1997 . See China statistical yearbook 1997-1998. Taken literally, it suggests that there might be too much investment in human capital in China. To give you a benchmark figure, in the United States and many other countries, there are estimates that the rate of return to human capital is as high as $15 \%$ to $20 \%$. This evidence suggests that the high ratio of physical capital investment to human capital investment in China might be appropriate.

Looking at how labor markets function in China, one realizes how misleading such a conclusion would be, even for an historical analysis of educational policy. Labor markets are the markets that price human capital services and reward people for their skills. Wage policy in China historically guaranteed a low rate of return to skilled labor, and there are still many restrictions. So the only thing we can conclude from standard rate of return to 
education analysis applied to historical Chinese data is that personal incentives to invest in skills are low.

The low private rate of return does not reflect the true rate of return in the late 1980s or early 1990s. Labor markets are so distorted in China that wages do not reflect this true marginal contribution of educated labor to the economy. In order to show this, I draw on an analysis of data whose collection was supported by the Ford Foundation working in cooperation with the Chinese Academy of Social Sciences. Fleisher and Wang (2001) analyze these data. An analysis of this data suggests that the social return to human capital is much higher than the private return, at least in the 1990s.

Instead of looking directly at market data and seeing what individuals are paid, they look at the productivity of education in the workplace in producing output. This is the direct return to education. It is not the full return to education.

Focusing only on the direct return, they arguably underestimate the full return to education. They do not measure all of the other benefits to education and training I mentioned earlier, and so their estimate constitutes a lower bound on the return to education. Their econometric studies suggest that the return to education is as high as $30 \%$ or $40 \%$. (Fleisher and Wang) The wages paid to skilled workers are only $10 \%$ of their marginal productivity in 1992. Unskilled workers are paid their marginal product. This demonstrates the extreme consequences of wage setting policies that fail to pay for productivity. Since workers get only a small fraction of their payment for skill, they have weak incentives to acquire skills.

The rate of return to education in production estimated by Fleisher and Wang is higher 
than anything found in the United States or Western Europe. And they underestimate the true rate of return to human capital. So the available microeconomic data suggest that there is in fact substantial under-investment in human capital. Labor markets in China gave the wrong incentives to workers in the late 1980s and early 1990s and likely do so today. If we compare estimates of the true productivity in education with wages paid, Chinese labor markets do not pay skill what it is worth.

\section{Policies to Foster Human Capital and Promote Eco- nomic Growth}

The low return reduces the incentives of individuals to acquire human capital. Chinese labor market policy and educational policy cause the national portfolio of investments to be distorted away from human capital toward physical capital investment. High rates of social return to investment can be realized by taking funds, even those borrowed from abroad, and funds created in the enterprises in China and from the new capital markets that are being proposed, to invest in human capital. Such a strategy would create national wealth.

One way to encourage education and job training is to subsidize it. That approach entails a substantial increase in government expenditure and may not be feasible. But China is spending far less of its GNP on education and training than many other developing countries.

Another way to foster human capital that entails less direct cost to government is 
to free up labor markets for human capital. A free labor market that allows the same kind of incentives to operate as increasingly govern capital markets and product markets in China, would go a long way toward promoting skill formation. This would have a powerful effect on promoting human capital. If persons can get a $30-40 \%$ return on human capital investments, they would willingly pay the costs of schooling. A $4 \%$ rate is not that profitable. Freeing up the labor market for skills would allow the forces of private incentives to operate. Giving individuals the fruits of their skilled labor would motivate people to acquire skill without costing the government anything. It would allow private incentives to operate to create the investment pools for human capital. By unleashing the forces of individual incentives to create human capital, China will create wealth and create pools of finance for physical capital from the savings of its educated workers. It will enhance its revenue from taxation.

Another policy that would promote growth is equalization of regional rates of return to human and physical capital. For some time now, Chinese policy has favored certain regions over other regions. It has also allowed local governments to play a dominant role in the financing of education. Richer regions have more funds for education than poorer regions. Eliminating regional disparity in wages and opening up markets to allow freedom of migration and pursuit of opportunities throughout China would enhance economic development. So would a centralized educational finance policy that serves to allocate governmental funds from the center more evenly across the regions and among rural and urban areas. The West, and rural areas, currently have low incomes and hence low support for education but a very high return to it. National income will be increased 
by allocating more resources for education and training to poorer regions.

Many Chinese object to freeing up labor market incentives. Opening the labor market might risk some increase in inequality in wages at least in the current generation. However, this policy produces the right incentives for people to acquire skills. Given the right rewards and access to capital markets to finance education, people will gladly pay tuition for schooling, which would produce higher salaries. China could rely on personal incentives to encourage schools to perform well as students shop among them and schools would gain resources directly from the students they educate.

For this system to operate effectively, credit markets for schooling should be developed to allow students to borrow against their future earnings. In the absence of such markets, only potential students from wealthy families can pay tuition charges which currently are as high as $50 \%$ of mean income. (Li) Inequality will be increased across the generations if only the rich can send their children to school.

A lesson that has been learned from many recent studies in the United States, Europe and other countries around the world is the value of the competition among schools in improving the performance of educational institutions. (Heckman, 2000) If China allows more private organizations, such as private business schools, technological institutes, and the like to operate, it can create an efficient educational infrastructure to promote the formation of human capital in China.

Another potentially important policy goal might be to promote ties between industry and universities. Some universities have begun such partnerships but there is much room for growth of these productive arrangements. Such partnerships allow the universities to 
respond to practical problems, and therefore help local industry solve some of the problems that accompany the introduction and improvement of technology. This will improve the efficiency of the region and will provide a source of financing by private industry for the educational enterprise.

In the United States, we have very successful firm - school relationships with school at all quality levels and not just those of distinguished universities with high-tech computer firms. Many lesser schools have formed valuable partnerships working closely with companies like General Motors and BASF that need workforce training. By creating incentives and allowing individuals and organizations to trade and to bargain in human capital and in physical capital markets, the educational infrastructure would be improved at no cost to government.

Creating incentives and developing capital markets would promote investment in human capital. It is not necessary to use funds from the center or to presume that education and skill formation should be governmentally supplied. Freeing up the labor market and the market for education would harness the forces that promote aqcuistion of skills by fostering the training of individual workers by firms, or encouraging individuals to train themselves in the workplace to be better farmers, better factory workers and better managers. If freeing up labor markets is not a possible policy option, educational expenditures could be increased and equalized across regions.

One of the best established empirical findings from around the world is that human capital is extremely valuable in working with high technology physical capital. The two complement each other. The current unbalanced investment strategy of China emphasizes 
physical capital over human capital. Ironically this strategy undermines the strategy for promoting physical capital investment. There are too few skilled workers to effectively operate the new technology being rapidly introduced into China. 


\section{Inequality}

In the short run, open labor markets might lead to greater inequality in wages, especially among the young and more able. Those persons are better able to benefit from the new

economy. In the long run, there will be less inequality as the population becomes more skilled.

However, even in the short run, fostering human capital might reduce inequality. A major source of income inequality in China is the difference between rural and urban incomes. These differences are due to policies of the Chinese government that create inequality. (Johnson, 2000; Fang, Wang and Yang, undated) Restrictions on labor migration from rural to urban areas has produced a disparity between urban and rural workers that in relative terms is among the highest in the world. Adding to this is the disparity in the funding of education between rural and urban areas. On average, the rural labor force has four years less schooling than the urban labor force. Finally, investment in physical capital has been disproportionately directed toward urban areas to the exclusion of rural areas. Open labor markets, open capital markets and geographical equity in spending on education will likely reduce inequality, not promote it.

Even if these policies raise inequality in the short run, inequality is not to be feared. Many Chinese officials fear inequality as a potential source of instability. However, greater inequality plays an important role in stimulating people to acquire skills. Making people more skilled is not socially harmful. Enhancing skills raises the productivity of the nation and makes more resources available to society at large. 
It is now accepted in China that open physical capital markets favor the better trader and the better investor. Human capital markets operate in the same way. But human capital is the asset that ultimately determines the wealth of China. Fostering human capital would likely reduce inequality in the long run. Freeing up human capital markets would create opportunities for everyone. The potential of the Chinese nation will be realized if its workers become educated and able to use modern skills to cope with the technology of the 21st century.

Current policy promotes a different kind of inequality. Region of birth now affects a person's chances to become skilled and the amount of capital with which they can work. Current tuition policies for secondary students discriminate against the children of the poor. Comparing policies, it is important to consider which inequality is less acceptable and not to assume that inequality is only associated with free labor markets. Indeed there is much evidence that opening up labor markets and capital markets would reduce inequality, even in the short run, and would contribute to overall political stability.

\section{Concluding Remarks}

The true rate of return to education in China might be as high as $30 \%$ or $40 \%$. Our knowledge of the true return to education is currently very limited as is our knowledge of the true rate of return to physical capital. More studies based on rigorous data are warranted. A more factually informed knowledge base will improve government decision making. If governments evaluate projects, whether they are human capital projects, or 
investment projects for dams, or investment projects for roads or bridges, or for factories, they will make better investment decisions. Project evaluations play an important role in keeping good investments and promoting good projects and eliminating the bad. The value of factually informed cost-benefit econometrics is extraordinarily high. Cost benefit studies produce value for local governments, for provincial governments and for the central government. Research that creates and collects much richer data sets on the returns to all kinds of human and physical capital to guide policy formation will improve policy making.

Despite the weak data base in China, the indications are clear. Economic performance will be enhanced by producing human capital and an educated work force. Economic performance will be enhanced by equalizing returns across all types of investments physical and human. Policies that foster human capital are entirely in keeping with the Chinese philosophy of government that emphasizes the dignity of the human being and the value of the individual in promoting it. Human capital has a high rate of return. It would be promoted by freeing up labor markets, eliminating regional disparities in wages and access to education, and by opening human capital markets to finance the formation of human capital. It would also be promoted by expanding the government budget on education and by equalizing expenditure across regions. However obtained, a more educated workforce would produce greater payoffs to capital and will produce greater national wealth. 


\section{References}

Chow, Gregory, 1993. "Capital Formation and Economic Growth in China", Quarterly Journal of Economics, August 809-842.

Chow, Gregory, 2001. China's Economic Transformation, Princeton University, forthcoming Oxford: Blackwell.

Fang, Cai, Denon Wang and Yang Du, 2002. "Regional Disparity and Economic Growth in China: The Impact of Labor Market Distortions," forthcoming China Economic Review, vol 13 (2/3).

Fleisher, Belton and Xiaojun Wang, 2001. "Skill Differentials, Return to Schooling and Market Segmentation in a Transition Economy: The Case of Mainland China", Ohio State University, Columbus, Ohio, January.

Heckman, James, 2000. "Policies to Foster Human Capital" (with discussion), Research In Economics, vol 54, \#1, pp. 3 - 82.

Johnson, D. Gale, 2000. "Reducing the Urban-Rural Income Disparity in China", Office of Agricultural Economics Research, University of Chicago, November 30, 2000.

Li, Wensheng, (undated). "Financing of Higher Education in China", Peking University. This can be obtained from her Web site at http://iee.hedu.pku.edu.cn/jjlw/jjlw0020/jjlw0020.asp.

Schultz, Theodore W., 1975. "The Value of the Ability to Deal with Disequilibria", Journal of Economic Literature 13, (September); 827-846.

Schultz, Theodore W., 1981. Investing in People, Berkeley: University of California Press. 
UNESCO, 1999. Statistical Yearbook United Nations Scientific and Cultural Organization.

Yang, Dennis, 2001. "Education and Allocative Efficiency: Household Income Growth During Rural Reforms in China", forthcoming, Journal of Development Economics. 
Table 1

Public Expenditures on Education as \% of GNP 1995

\begin{tabular}{|ll|}
\hline World & $\mathbf{5 . 2}$ \\
\hline China & 2.5 \\
\hline Philippines & 3.0 \\
\hline Thailand & 4.1 \\
\hline India & 3.3 \\
\hline Malaysia & 4.7 \\
\hline Singapore & 3.0 \\
\hline Pakistan & 2.8 \\
\hline Turkey & 2.2 \\
\hline South Korea & 3.7 \\
\hline Egypt & 4.8 \\
\hline Mexico & 4.9 \\
\hline Brazil & 5.1 \\
\hline Argentina & $3.8^{*}$ \\
\hline United States & $5.4^{*}$ \\
\hline Japan & $3.6^{*}$ \\
\hline Canada & $6.9^{*}$ \\
\hline Germany & 4.8 \\
\hline Russian Federation & 3.5 \\
\hline Poland & 5.2 \\
\hline Hungary & 5.3 \\
\hline
\end{tabular}

* 1994

Source UNESCO, 1999 